\title{
The Study of Ectoparasites and Mesoparasites in Turtles (Testudo Graeca Graeca) in the Region of Laghouat (South of Algeria)
}

\author{
LAKEHAL Kheira ${ }^{1}$, SAIDI Radhwane ${ }^{2}$, MIMOUNE Nora ${ }^{3-4}$, BENACEUR Farouk ${ }^{1}$, BAAZIZI Ratiba ${ }^{3}$, CHAIBI \\ Rachid $^{1}$, ADJEB Oum Keltoum ${ }^{1}$, SOUIEHI Khadidja ${ }^{1}$. \\ ${ }^{1}$ Department of Biology, Faculty of Sciences, Water, Soil and Environment resource Laboratory and \\ Laboratory of Biological and Agronomic Sciences (LSBA), Telidji Amar University, Laghouat, Algeria. \\ ${ }^{2}$ Department of Agronomy, Telidji Amar University, BP 37G, Ghardaïa Road, 03000 Laghouat, Algeria. \\ ${ }^{3}$ Higher National Veterinary School, Bab-Ezzouar, Algiers, Algeria. \\ ${ }^{4}$ Institute of Veterinary Sciences, Laboratory of biotechnology related to animal breeding, University Saad \\ Dahleb, BP: 270, Soumaa road, Blida, Algeria. \\ * corresponding author: nora.mimoune@gmail.com
}

Bulletin UASVM Veterinary Medicine 77(1)/2020

Print ISSN 1843-5270; Electronic ISSN 1843-5378

doi:10.15835/buasvmcn-vm: 2020.0001

\begin{abstract}
This study was carried out in order to identify the different parasites (ecto and mesoparasites) infesting the tortoise Testudo graeca graeca. For this, a population of 24 tortoises was studied from mid-March to May 2018, in the region of Aflou-Laghouat, within two sites: Djellel and Oued Sebgag. The turtles were captured at the time of their activity; sex, age, body weight, total length of the shell and body height were determined. A careful search for parasites has been carried out using various recommended techniques. A total of 126 Hyalomma aegyptium ticks were identified, with an overall prevalence of $71 \%$, an average intensity of 7.4 and an abundance of 5 ticks per individual. The stool examination identified six mesoparasites, namely: Angusticaecum holopterum, Enterobius vermicularis, Strongylus sp, Nematodirus sp, Trichostrongylus sp, Fasciola hepatica. The sex of the host showed a significant influence on the parasitic infestation: the females were four times more infested than the males.
\end{abstract}

Keywords : Testudo graeca graeca, turtle, tick, parasite

\section{Introduction}

Testudo graeca Linnaeus, 1758 is a widely distributed species found in three continents (Africa, Europe and Asia) (Fritz et al., 2007; Tavassoli et al., 2007). Habitat is in the Mediterranean forests, coastal regions and sub-coasts, in all arid and hot zones covered with steppe-type vegetation (Slimani et al, 2001; Ben Kaddour et al, 2005). Also, in extremely varied environments and climates (Ferri, 1999; Carretero et al., 2005). It is considered to be the only species of tortoises present in Algeria (Fritz et al., 1996).
Several factors lead to the threat and decline of this species, where according to the International Union for Conservation of Nature and Natural Resources (IUCN), it has been classified as a vulnerable species (IUCN, 1996). This species faces several hazards; among the latter the health problem which has a lot of repercussions on its survival. Indeed, the problems have different origins: bacterial, viral and even parasitic. In this sense, many helminths parasitize turtles (Bouamer and Morand, 2000; Bouamer et al., 2003), as well as ectoparasites, particularly ticks and 
leeches (Burridge and Simmons 2003). Parasites can indirectly affect the survival of the host by increasing its susceptibility to predation or by reducing its competitiveness (Scott, 1988). They can also have effects on reproduction (Anderson and May, 1978) and, as a result, its survival is really threatened.

On the other hand, the importance of this species in the ecosystem is considerable; it is involved the ecological balance of the region, the object of its habitat. Therefore, reducing its number or even distinguishing it will have harmful consequences on the balance of the environment.

In Algeria, especially in Aflou (South of Algeria), there is a terrible lack of solid references on this species especially those which treat the problem of parasitism. Therefore, the present study aims firstly, to research the ectoparasites and the mesoparasites existing in the wild Testudo graeca graeca of the Aflou region. Secondly, to research the parasitic load by applying some parasitic indices of tortoises.

\section{Materials and methods}

\section{Study areas}

Our study was carried out during the turtle activity period, from mid-March until the end of May 2018 in Aflou (Wilaya of Laghouat), which occupies an area of $1216 \mathrm{Ha}$. This area is located on the mountains of the Saharian Atlas, in the heart of Djebel Amour at an altitude of $1400 \mathrm{~m}$ and oriented northwest of Laghouat. Two sites were chosen for the capture of turtles: Djellel site is located in the heart of the Djebel Amour mountains $\left(34^{\circ} 27\right.$ ' $\mathrm{N}$, $2^{\circ} 13^{\prime} \mathrm{E}$ ), $30 \mathrm{~km}$ northeast of the city of Aflou and Oued Sebgag site ( $\left.34^{\circ} 21^{\prime} \mathrm{N}, 2^{\circ} 00^{\prime} \mathrm{E}\right), 20 \mathrm{~km}$ west of Aflou (C.G.F., 2008).

Turtle capture

The capture was carried out by hand at the time of turtle activity by searching intensively inside the tufts of vegetation. The turtles were transported in air boxes to carry out the desired study. We took measurements regarding body weight, total shell length and body height. Also, we determined the age of turtles by counting the number of growth rings (Stubbs and Swingland, 1985; Willemsen and Hailey, 1999; Lagarde et al., 2001; Wilson and Tracy, 2003) and sex based on morphological characters previously mentioned (Highfield, 1990; Díaz-Paniagua and Andreu, 2005).

\section{Tick collection}

We carried out a physical examination (legs, neck, tail, etc.) on the captured turtles, in order to remove the ticks. The extraction was carried out using forceps and the ticks were stored in ethanol at $75^{\circ}$, in labeled tubes (Boyd, 1951). The identification of the specimens was carried out under a binocular magnifying glass, using the morphological keys available in specialized works (Séguy, 1923, 1934, 1944; Maa, 1967, 1969).

\section{Study of digestive parasites}

The study of digestive parasites was carried out by two methods: sedimentation and flotation (Jean, 1993).

\section{Epidemiological evidence}

We calculated the following indices: prevalence, mean intensity and abundance (Bush et al., 1997).

- Prevalence (P): $\operatorname{Pr}(\%)=$ (The number of individuals infested with a host species / the total number of hosts examined) x 100 .

- Average intensity (IM): I = the total number of individuals of a parasite species / the number of hosts infested by the parasite.

- Abundance (AB): $A B=$ the total number of individuals of a parasitic species / the total number of hosts examined.

\section{Statistical analysis}

For the analysis of the results: calculation of epidemiological indices, analysis of growth parameters, determination of regression equations and correlation coefficients, we used descriptive and quantitative statistical tools (SPSS, IBM Corp Ver. 20.0).

\section{Results and discussion}

Our study focused on a population of 24 turtles belonging to the family of Testudinidae. Their characteristics have been mentioned in Table 1.

\section{Demographic analysis \\ Sex ratio}

Sex ratio the results showed that the males are numerous compared to the females and the percentages calculated are respectively $58 \%$ and $42 \%$. Fluctuations in this ratio are due to the activity rate and the behavior of the animal during this period of the year. The females are found most of the sedentary time where they seek the good place of laying. While the males seem a little active 
Table 1. General characteristics of the population of the region of Aflou

\begin{tabular}{|c|c|c|c|c|c|c|c|c|}
\hline \multirow{2}{*}{ Site } & \multirow{2}{*}{ Sex } & \multirow{2}{*}{$\mathbf{N}$} & \multicolumn{2}{|c|}{ Age (year) } & \multicolumn{2}{|c|}{ Weight (gr) } & \multicolumn{2}{|c|}{ Size $(\mathrm{cm})$} \\
\hline & & & Max & Min & Max & Min & Max & Min \\
\hline \multirow{2}{*}{ Aflou } & 우 & 10 & 16 & 7 & 1739 & 373 & 22 & 13.2 \\
\hline & o & 14 & 16 & 6 & 890 & 223 & 19.1 & 10.5 \\
\hline
\end{tabular}

Max =Maximal ; Min= Minimal ; N= Effectif.

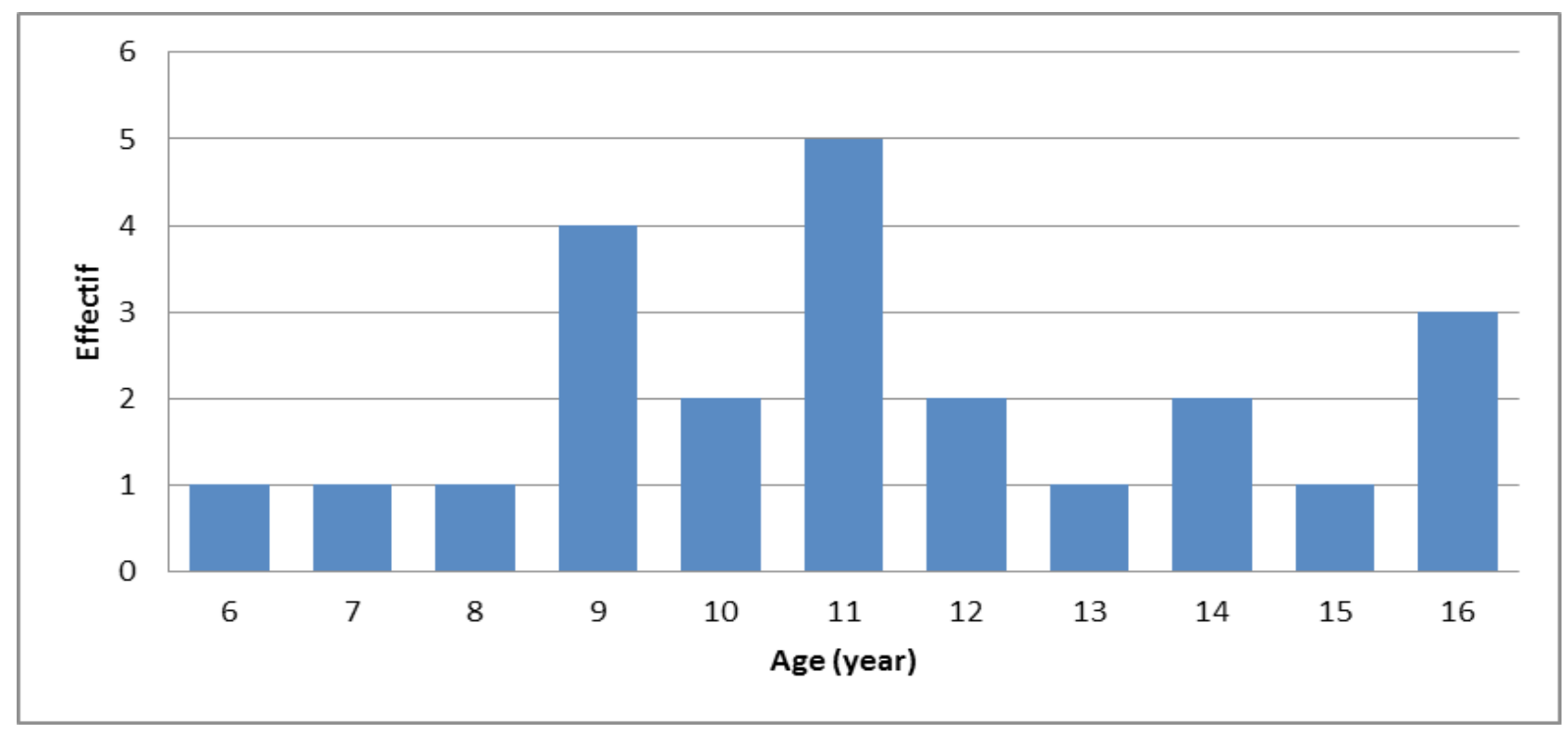

Figure 1. Distribution of numbers by age class among turtles in the region of Aflou

where they look for food and females for mating (Diaz-Paniagua et al., 1996).

\section{Age structure}

The distribution of numbers by class of turtles age in the Aflou region revealed the presence of three peaks ; the first to the 9th age with a number of 4 individuals, the second and the third to the 11th and 16th age including the respective numbers of 5 and 3 individuals (Figure 1).

The age range varies between 6 and 16 years. Lambert (1982) reported that natural populations of this species in Morocco can reach more than 50 years. The differences in longevity observed in our result are surely linked to the used method; it is quite clear that age is underestimated by the method of counting growth rings, especially in adults because of the scaling and the tightening of stopping lines frequently observed in chelonians (Castanet and Cheylan, 1979).

\section{Results of the parasitological study}

The observation of the morphological criteria of the different pathogenic forms, in the turtles Testudo greaca greaca allowed us to identify a single species of tick and 06 genera of helminthes (Tab. 2).

\section{Analysis of parasitic indices Ticks case}

A total of 126 male and female ticks have been identified, male ticks are the most dominant with 100 individuals (79\%) against 26 female ticks (21\%). This fluctuation can be due to the presence and the dynamics of the host species, its immune state or to the reproductive behavior of this tick species. The same results have been obtained by other authors around the world (Siroky et al., 2005 ; Siroky et al., 2009 ; Brianti et al., 2010). 
Table 2. Results of the parasitological study

\begin{tabular}{cccc}
\hline \multirow{2}{*}{ Phylum } & Class & Family & Genus \\
\hline Arthropods & Arachnida & Emblyommidae & Hyalomma \\
\hline \multirow{2}{*}{ Nemathelminthes } & & Strogylidae & Strongylus \\
\cline { 2 - 4 } & Nematoda & Molineidae & Nematodirus \\
\cline { 2 - 4 } & & Trichostrongylidae & Trichostrongylus \\
\cline { 2 - 4 } & & Ascarididae & Angusticaecum \\
\hline Platyhelminthes & Trematoda & Fasciolidae & Enterobius \\
\hline
\end{tabular}

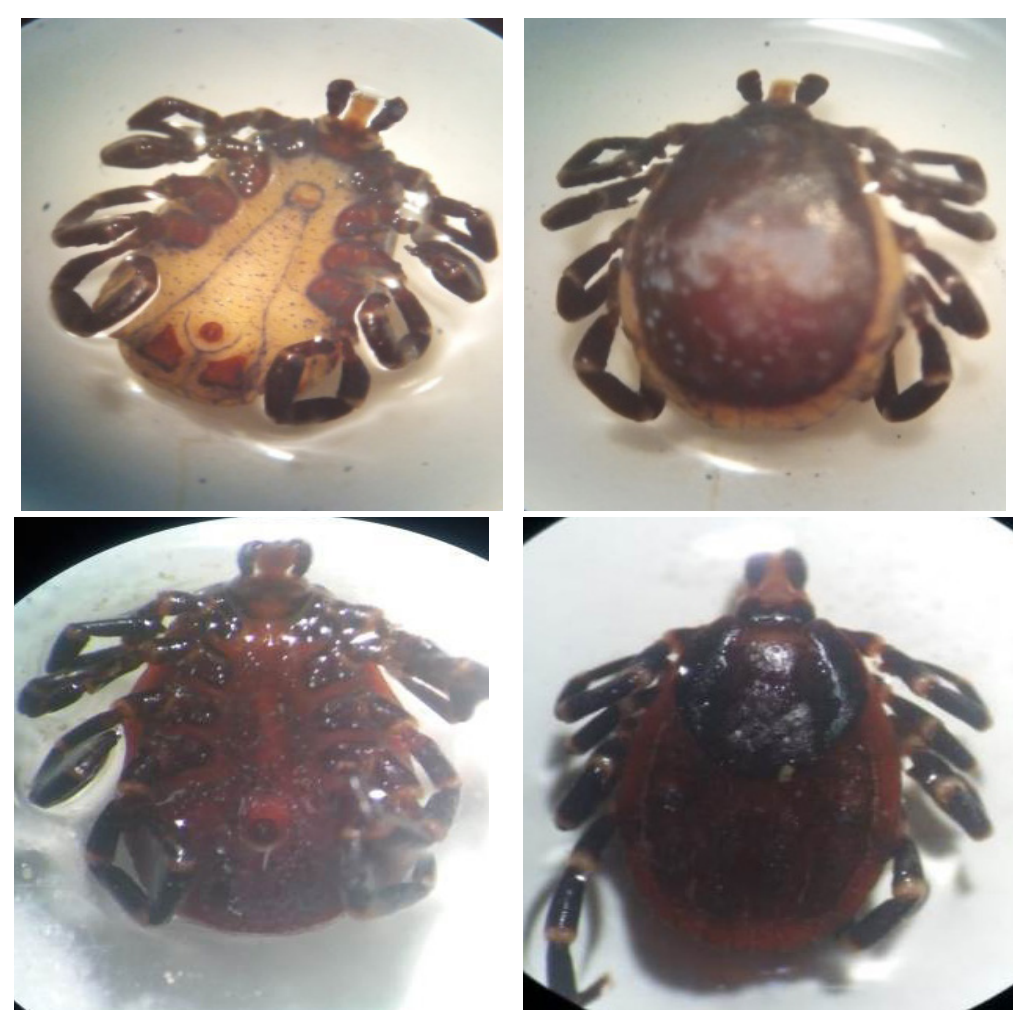

Figure 2. Hyalomma aegyptium:

A : Male (dorsal view), B : Male (ventral view), C : Female (dorsal view), D : Female (ventral view)

The number of ticks in Oued sebgag site was 102 (80, 95\%) (81 males, 21 females), while in Djellel site it was 24, (19,05\%) (19 males, 5 females). This variation is probably due to the difference between the height of the two sites and climatic conditions (Apanaskevich and Oliver, 2014). Another study by Tiar et al., 2016 proved that were infested by adult ticks only (four males and one female).

The only tick species found was Hyalomma aegyptium (Figure 2). Indeed, this species is specific to Testudo graeca (Hoogstraal and Kaise,
1960; Trevor and Al-Yaman, 1985; Apanaskevich, 2003). This result was also reported in Tunisia by Gharbi et al. (2015) and in Malta by Loporto et al. (2017).

The overall prevalence was $71 \%$, with a remarkable difference between males and females where the values were $57 \%$ and $90 \%$ respectively (Figure 3). Tiar et al., 2016 found that the prevalence was only $9 \%$ in Laghouat.

Males were more abundant compared to females, but the infestation was much more in females. This can be explained by the sedentary 
behavior of females during this period of the year, which gives enough time for the fixation of ticks. Similar results were reported for other populations of Testudo, in Syria $82.85 \%$ and in Lebanon $91.66 \%$, on the other hand in Iran $28.57 \%$.

In Oued Sebgag site, the prevalence was $69,23 \%$ (57,14\% males,83,33\% females), while in Djellel site was $72,73 \%$ (57,14\% males, $100 \%$ females). These results are very similar between the two sites.

The average intensity for both sexes was varied between 7.2 and 7.6 per individual, while the abundance was 5 ticks per individual. In Oued Sebgag site, the average intensity was 11,33 ticks and the abundance was 7,85 ticks per individual, while in Djellel site, the average intensity was 3 ticks and abundance was 2,18 ticks per individual.

Relationship between parasitic load and growth parameters

The calculated mathematical model of the correlation test showed that all the parameters
(Lt, Pt, Ha, and age) had no relation to the parasite load rates (Tab. 3 ).

The tick infestation does not depend on the intrinsic factors of the animal, but much more on the environmental factors linked to the biotopes. Such as temperature, humidity, season. The geographic location of the study area links several hypotheses to explain the high parasite load. Climatic factors are essential elements influencing the distribution of ticks, their life cycle, the seasonal variation in their activity and behavior, as well as population dynamics (Daniel and Dusbabek, 1994).

\section{Helminths case}

The prevalence in the general population revealed the presence of 6 parasites (Nematodirus sp, Fasciola hepatica, Trichostrongylus sp, Strongylus sp, Enterobius vermicularis, Angusticaecum holopterum) (Figure 4). All six parasites were found in Oued Sebgag and Djellel sites.

Nematodes and trematodes are very common in tortoises (Hedley et al., 2012). Results in similar

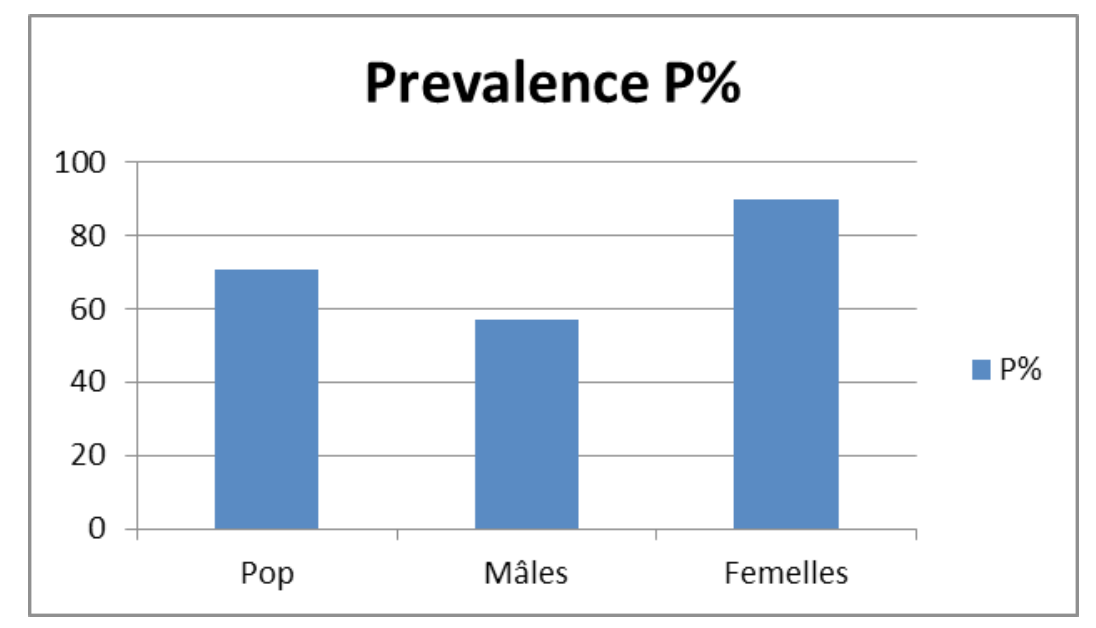

Figure 3. Histogram of parasite prevalence of ticks in the Aflou region

Table 3. Relationship between parasitic load and growth parameters

\begin{tabular}{lcccl}
\hline \multicolumn{1}{c}{ Parameter } & Function & Regression equation & $\mathbf{R}^{2}$ & Observation \\
\hline Pt $(\mathbf{g r})$ & $\mathrm{Pt}=\mathrm{f}($ tique $)$ & $\mathrm{Pt}=0.0062 \mathrm{Age}+0.5538$ & 0.12 & No correlation \\
\hline $\mathbf{L t}(\mathbf{c m})$ & $\mathrm{Lt}=\mathrm{f}(\mathrm{tique})$ & $\mathrm{Lt}=1.1519$ Age -12.564 & 0.23 & No correlation \\
\hline $\mathrm{Ha}(\mathrm{cm})$ & $\mathrm{Ha}=\mathrm{f}($ tique $)$ & $\mathrm{Ha}=0$ 1.8246Age -8.9536 & 0.26 & No correlation \\
\hline Age $(\mathrm{an})$ & Age $=\mathrm{f}(\mathrm{tick})$ & Age $=1.047 \mathrm{Age}-7.0304$ & 0.18 & No correlation \\
\hline
\end{tabular}


studies showed another species for exemple Alaeuris, Mehdiella, Tachygonetria and Atractis (Traversa et al., 2005; Chávarri et al., 2012), but all studies proved that Angusticaecum holopterum is the main common species among chelonians; it has been reported in Africa, Europe, Western Asia and South America (Sprent, 1984; Schilliger, 1992; Jacobson, 1994). It were identified in tortoises of the genus Testudo (T. hermanni, T. graeca and T. marginata) in Italy by Traversa et al. (2005), in

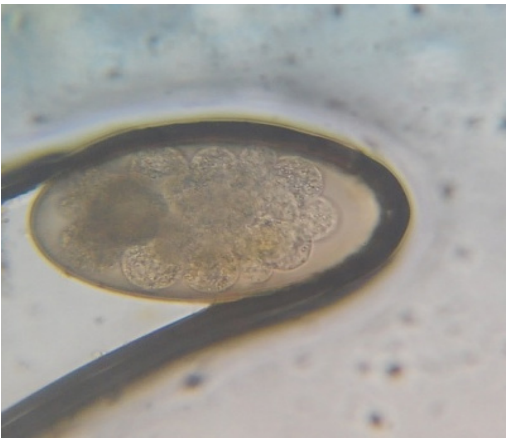

Nematodirus sp

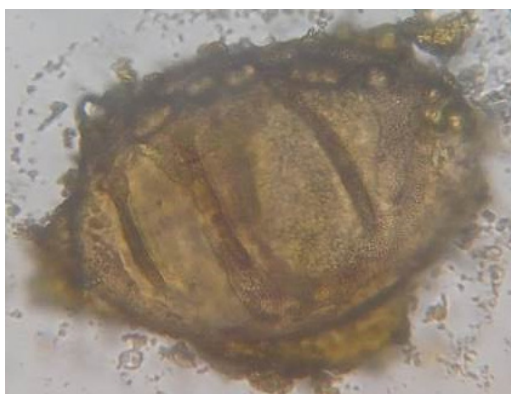

Strongylus sp

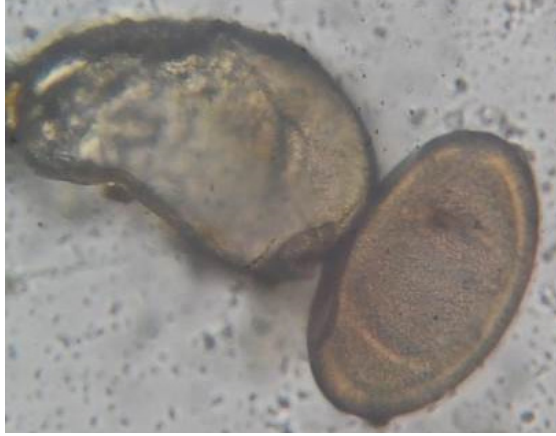

Fasciola hepatica

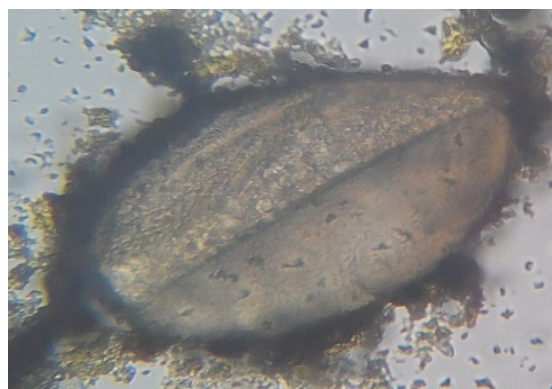

Enterobius vermicularis

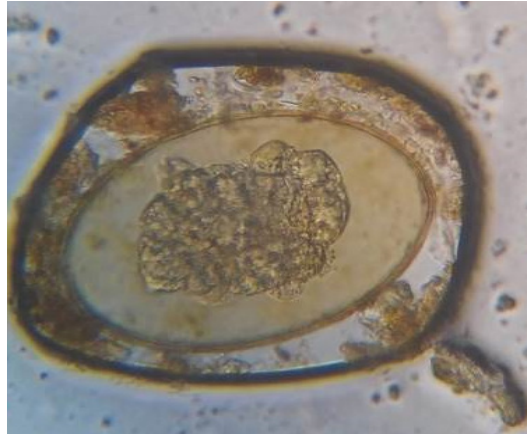

Trichostrongylus sp

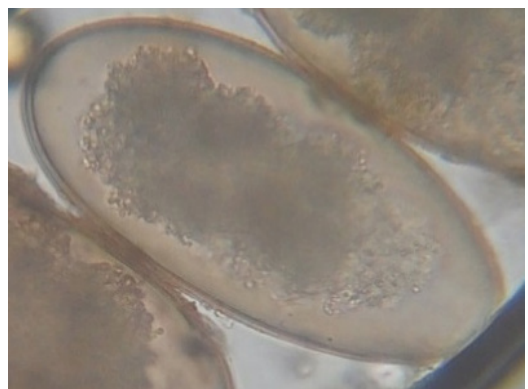

Angusticaecum holopterum

Figure 4. The different parasitic forms of the digestive tract of Testudo graeca graeca

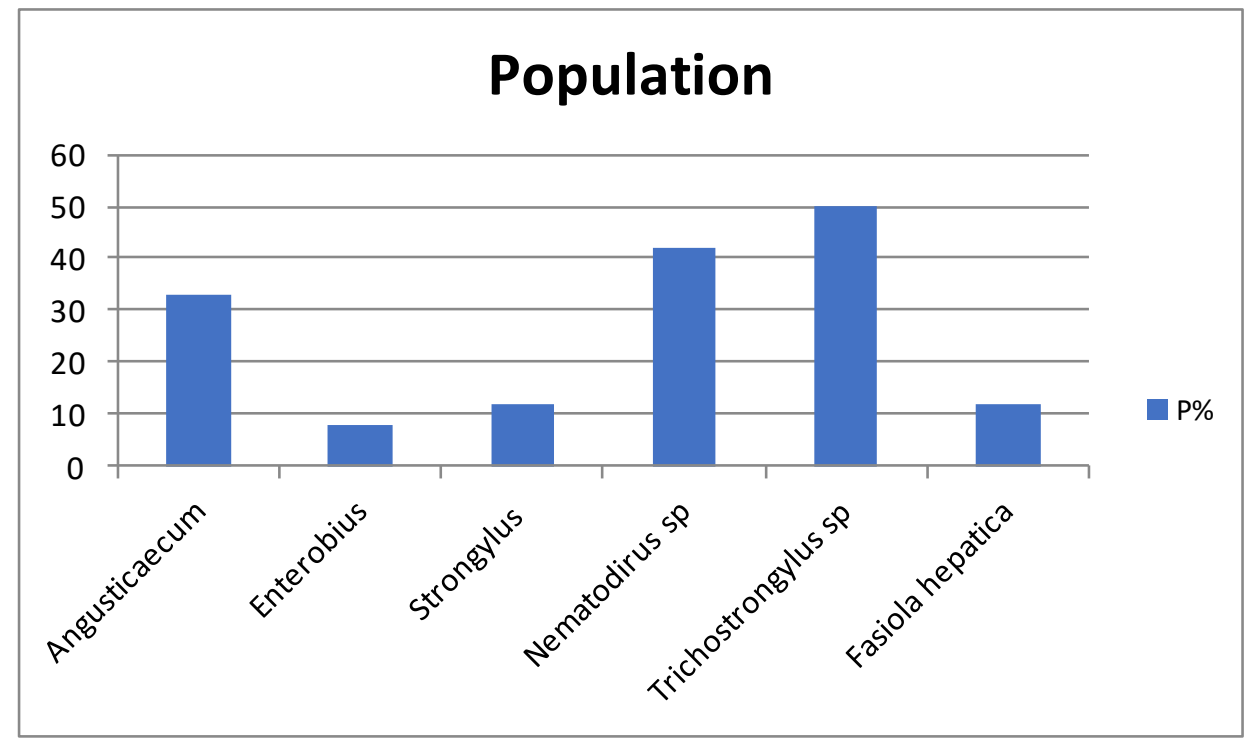

Figure 5. Histogram of the overall parasite prevalence of mesoparasites in the Aflou region 


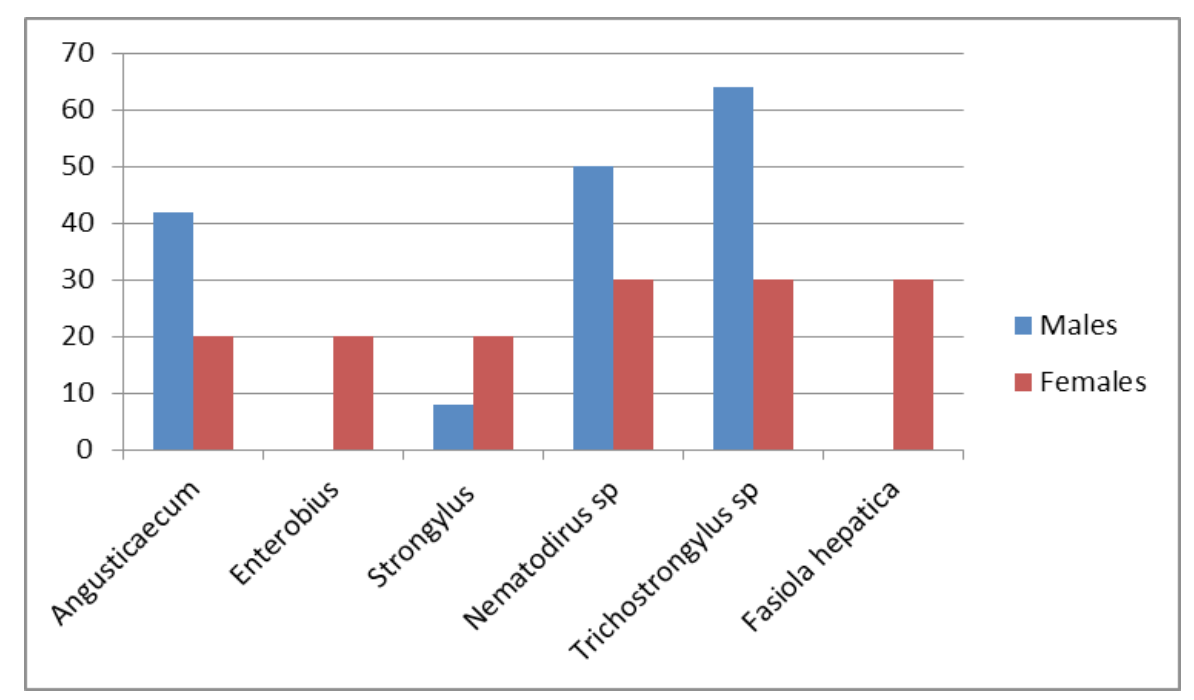

Figure 6. Histogram of parasite prevalence in males and females of mesoparasites in the Aflou region

Southern Spain by Chávarri et al. (2012) and in Germany by Hallinger et al. (2018).

The prevalence showed moderate fluctuations between the genera of the parasites identified (Figure 5). Where Trichostrongylus represents 50\%, Nematodirus sp 42\%, Angusticaecum holopterum 33\%, Fasciola hepatica and Strongylus sp $12 \%$, Enterobius vermicularis $8 \%$.

The parasite infestation by the sex of the host showed that the females are infested with 06 parasites while this number was reduced in the males where there were only 04 parasites. The prevalence index varied from $20 \%$ to $30 \%$ in females, and from 08 to more than $60 \%$ in males (Figure 6).

\section{Conclusion}

Our study showed that relative growth and height-weight relationship is isometric, while age has no influence on growth in weight and length. Concerning parasitism: from the examination of the 24 turtles, we found a single species of ectoparasite: Hyalomma aegyptium and six species of mesoparsites: Angusticaecum sp, Enterobius vermicularis, Strongylus sp, Nematodirus $s p$, Trichostrongylus sp, Fasciola hepatica. The results obtained open up a large number of study perspectives for both the host and its environment and the parasite community it hosts. So it would be interesting to undertake similar studies over several cycles and in various biotopes. Also, to carry out further studies in all areas (ecology, biology, genetics; epidemiology) that can help better conservation of the species which enjoys with a protected status.

Acknowledgments. This research did not receive any specific grant from funding agencies in the public, commercial, or not-for-profit sectors.

\section{References}

1. Anderson RM, May RM (1978). Regulation and stability of host-parasite population interactions. J. Anim. Ecol. Vol. 47. 219-247.

2. Apanaskevich DA (2003). K diagnostike vida Hyalomma (Hyalomma) aegyptium (Acari, Ixodidae) (To diagnostics of Hyalomma (Hyalomma) aegyptium (Acari: Ixodidae). Parazitologija. Vol. 37. 47-59.

3. Apanaskevich DA, Oliver JH (2014). Life cycle and natural history of ticks. Oxford: Oxford University.

4. Ben Kaddour K, El Mouden TS, Frédéric L, Xavier B (2005). Dimorphisme sexuel et cinétique de croissance et de maturation chez Testudo graeca graeca, dans les Jbilets Centrales, Maroc, Rev. Écol. Vol. 60, no 3. 256-278.

5. Bouamer S, Morand S (2000). Oxyuroids of palearctic testudines: new definition of the genus Thaparia, Ortlepp, 1933 (Nematoda : Pharyngodonidae), redescription of T. thapari thapari, and descriptions of two new species. Comp Parasitol. Vol. 67. 169-180.

6. Bouamer S, Morand S, Kara M (2003) Redescription of four species of Mehdiella from Testudinidae, with a key to the species and discussion on the relationships among the species of this genus. Parasite. Vol. 10. 333-342.

7. Boyd E (1951). The external parasites of birds: A reviw. The Wilson Bulletin. Vol. 63, no 4. 363-369.

8. Brianti E, Dantas-Torres F, Giannetto S, Risitano A, Brucato G, Gaglio G, Otranto D (2010). Risk for the introduction 
of exotic ticks and pathogens into Italy through the illegal importation of tortoises, Testudo graeca. Med. Vet. Entomol. Vol. 24. 336-339.

9. Burridge MJ, Simmons LA (2003). Exotic ticks introduced into the United States on imported reptiles from 1962 to 2001 and their potential roles in international dissemination of diseases. Veterinary Parasitology. Vol. 113. 289-320.

10. Bush AO, Kevin DL, Jeffrey ML, Allen WS (1997). Parasitology meets ecology on its own terms. J. Parasitol. Vol. 83. 575-583.

11. C.G.F. (2008). Conservation des Gardes Forestiers de La wilaya de Laghouat: Inventaire des espèces floristiques et faunistiques de la wilaya de Laghouat.

12. Carretero MA, Znari MD, Harris J, Macé JC (2005). Morphological divergence among populations of Testudo graeca from West-Central Morocco. Animal Biology. Vol. 55, no 3. 259-279.

13. Castanet J, Cheylan M (1979). Les marques de croissance des os et des écailles comme indicateur de l'âge chez Testudo hermanni et Testudo graeca (Reptilia, Chelonia, Testudinidae). Can. J. Zool. Vol. 57, no 8. 1649-1655.

14. Daniel M, Dusbabek F (1994). Micrometeorological and microhabitats factors affecting maintenance and dissemination of tick-borne diseases in the environment. In Sonenshine, D. E., et Mather, T. N. Ecological dynamics of tick-borne zoonoses. Oxford University Press. 91-138.

15. Díaz-Paniagua C, Andreu AC (2005). Tortuga mora-Testudo graeca. En : Enciclopedia Virtual de los Vertebrados Españoles. Carrascal, L. M., Salvador, A. Museo Nacional de Ciencias Naturales, Madrid. 41p.

16. Díaz-Paniagua C, Keller C, Andreu AC (1996). Clutch frequency, egg and clutch characteristics, and nesting activity of spur-thigheed tortoises, Testudo graeca, in southwestern Spain. Can. J. Zool. Vol. 74, no 3. 560-564.

17. Ferri V (1999). Guide des tortues, 190 espèces du monde entier. Paris. Delachaux et Niestlé S. A. 255p. (Les compagnons du naturaliste).

18. Fritz U, Bischoff W, Martens H, Schmidtler JF (1996). Variabilität syrischer Landschildkröten (Testudo graeca) sowie zur Systematik und Zoogeographie im NahenOsten und in Nordafrika. Herpetofauna. Vol. 18, no 104. 5-14.

19. Fritz U, Hundsdörfer AK, Široký P, Auer M, Kami H, Lehmann J, Mazanaeva LF, Türkozan O, Wink M (2007). Phenotypic plasticity leads to incongruence between morphology-based taxonomy and genetic differentiation in western Palaearctic tortoises (Testudo graeca complex; Testudines, Testudinidae). Amphibia- Reptilia. Vol. 28. 97 121.

20. Gharbi M, Rjeibi MR, Rouatbi M, Mabrouk M, Mhadhbi M, Amairia S, Amdouni Y, Boussaadoun MA (2015). Infestation of the spur-thighed tortoise (Testudo graeca) by Hyalomma aegyptium in Tunisia. Ticks and Tick-borne Diseases. Vol. 6. 352-355.

21. Hallinger MJ, Taubert A, Hermosilla C, Mutschmann F (2018). Occurrence of health-compromising protozoan and helminth infections in tortoises kept as pet animals in Germany. Parasites et Vectors. Vol.11. 1-12.
22. Hedley J, Eatwell K, Shaw D (2012). Survey of gastrointestinal parasites in tortoises in the UK. Proceedings of the British Small Animal Veterinary Association Conference, Birmingham. 459p.

23. Highfield AC (1990). Tortoises of North Africa; taxonomy, nomenclature, phylogeny and evolution with notes on field studies in Tunisia. J. Chel. Herp.. Vol. 1, no 2. 1-56.

24. Hoogstraal H, Kaise MN (1960). Some host relationships of the tortoise tick, Hyalomma (Hyalommasta) aegyptium (L.) (Ixodoidea, Ixodidae) in Turkey. Ann Entomol Soc Amer. Vol. 53. 457-458.

25. IUCN (1996). IUCN Red list of threatened animals. IUCN, Gland, Switzerland.

26. Jacobson ER (1994). Causes of mortality and diseases in tortoises : A review., J. Zoo Wildl. Med. Vol. 25. no1, 2-17.

27. Jean JR (1993). Copro-parasitologie pratique : Intérêt et méthodologie, notions sur les parasites du tube digestif. Montréal. Canada. Estem/Aupelf. 88p. (Universités Francophones).

28. Lagarde F, Bonnet X, Henen BT, Corbin J, Nagy KA, Naulleau G (2001). Sexual size dimorphism in steppe tortoises (Testudo horsfieldi): growth, maturity and Individual Variation. Can. J. Zool. Vol. 79. 1433-1441.

29. Lambert MRK (1982). Studies on the groth, structure and abundance of the Mediterranean spur-thighed tortoise, Testudo graeca L. In field populations. Journal of Zoology. Vol. 196, no 2. 165-189.

30. Maa TC (1967). A synopsis of diptera pupipara of Japan. Pacific Insects. Vol. 9, no 4. 727-760.

31. Maa TC (1969). A revised checklist and concise host index of Hippoboscidae (Diptera). Pacific Insects Monograph. Vol. 20. 261-299.

32. Schilliger L (1992). Les affections parasitaires chez les chéloniens. Applications en consultation vétérinaires. Prophylaxie - Thérapeutique. In: Premier congrès international de pathologie des chéloniens. Gonfaron, Var, France. 25-27.

33. Scott ME (1988). The impact of infection and disease on animal populations: implications for conservation biology. Conservation Biology. Vol. 2, no 1. 40-56.

34. Séguy E (1923). Diptères anthomyides. Paris. Office Central de faunistique. Les presses universitaires de France et Paul Lechevalier et fils. 393p. (Faune de France).

35. Séguy E (1934). Diptères (Brachycères Muxidae Acalyptae et Scatophagidae). Paris. Office Central de faunistique. Les presses universitaires de France et Paul Lechevalier et fils. 831p. (Faune de France).

36. Séguy E (1944). Insectes Ectoparasites (Mallophages, Anoploures, Siphonaptères). Paris. Office Central de faunistique. Paul Lechevalier et fils. 681p. (Faune de France).

37. Siroky P, Kamler M, Modrý D (2005). Prevalence of Hemolivia mauritanica (Apicomplexa: Adeleina: Haemogrigarinidae) in natural populations of tertoises of the genus Testudo in the east Mediterranean region. Folia parasitological. Vol. 52. 359-361. 
38. Široky P, Mikulícek P, Jandzík D, Kami H, Mihalca AD, Rouag R, Kamler M, Schneider C, Záruba M, Modry D (2009). Co-distribution pattern of a haemogregarine Hemolivia mauritanica (Apicomplexa: Haemogregarinidae) and its vector Hyalomma aegyptium (Metastigmata: Ixodidae). J. Parasitol. Vol. 95. 728-733.

39. Slimani T, El Hassan, El Mouden EH, Ben Kaddour $\mathrm{K}$ (2001). Structure et dynamique d'une population de Testudo graeca, L. 1758 dans les Jbilets Centrales, Maroc. In : Chelonii 3. Proceedings of the international congress on Testudo Genus. March7-10. Gonfaron. France.

40. Sprent JFA (1984). Ascaridoid Nematodes, In: Diseases of Amphibians and Reptiles Ed. Hoff GL. Frye FL et Jacobson ER., Plenum Press, NY. 219-245.

41. Stubbs D, Swingland IR (1985). The ecology of a Mediterranean tortoise (Testudo Hermanni): a declining population. Can J Zool. Vol. 63. 169-180.

42. Tavassoli E, Rahimi-Asiabi N, Tavassoli M (2007). Hyalomma aegyptium on spur thighed tortoise (Testudo graeca) in Urmia region west Azerbaijan, Iran. Iranian Journal of Parasitology. Vol. 2. 40-47.

43. Traversa D, Capelli G, Iorio R, Bouamer S, Cameli A, Giangaspero A (2005). Epidemiology and biology of nematodofauna affecting Testudo hermanni, Testudo graeca and Testudo marginata in Italy. Parasitol Res. Vol. 98. 14-20.

44. Trevor P, Al-Yaman F (1985). Attachment sites of the tortoise tick Hyalomma aegyptium in relation to tick density and physical condition of the host. J parasit. Vol. 71, no 3. 287-289.

45. Willemsen RE, Hailey A (1999). Variation of adult body size of the tortoise Testudo hermanni in Greece: proximate and ultimate causes. J. Zool. Vol. 248 ; 379-396.

46. Wilson DS, Tracy CR (2003). Estimating age of turtles from growth rings: a critical evaluation of the technique. Herpetologica. Vol. 59. 178-194. 